\title{
The Impact of Training Programs on Professional Learning and Development (PLD).
}

\section{A study for Romania}

Horațiu Catalano, Ion Albulescu, Cristian Stan 


\title{
The Impact of Training Programs on Professional Learning and Development (PLD). A study for Romania
}

\author{
Horațiu Catalano $^{\mathrm{a}^{*}}$, Ion Albulescu ${ }^{\mathrm{b}}$, Cristian Stan $^{\mathrm{c}}$ \\ ${ }^{a, b, c}$ Educational Sciences Department, Babes Bolyai University, Cluj-Napoca, Romania \\ *Corresponding author: horatiu.catalano@ubbcluj.ro
}

\section{Abstract}

\section{Keywords:}

Professional Learning and Development (PLD), continuous training, training program, teachers competencies
Training programs focused on professional learning and development are meant to provide teachers with opportunities to develop their professional competencies for teaching in specific domains. These programs represent an important branch of the educational system in Romania. In the study that we have initiated we have tested and validated the hypothesis that identifying professional training needs and offering specific courses in order to develop the professional competencies represents a key condition for teachers' effectiveness in terms of their professional learning and development. The methods and instruments for educational research that we used in the present study are both qualitative and quantitative, based on questionnaires, individual interviews and focus group interviews. The reason why we opted for the mixed methods is because quantitative research throughout questionnaires does not always allow participants to explain their choices or the meaning of the questions.

The quantitative survey was carried out on a non-probabilistic sample (770 teachers) and the focus groups were conducted with groups of 10 randomly selected respondents from the training program. All the teachers participating in our study are from pre-university education and have participated in continuing education programs accredited by the Department of Educational Sciences of the Faculty of Psychology and Educational Sciences.

\section{Zusammenfasung}

Schlüsselwort:

Professionelles

Lernen und

Entwicklung,

Kontinuierliches

Training,

Trainingsprogramm,

Lehrerkomptenzen
Die verschiedenen maßgeschneiderten Fobildungsangeboten geben Lehrer die Möglichkeit sich fort und weiterzubilden in den Unterrichtsfächer für die sie sich spezialisiert haben und Sie selbst unterrichten.

Diese Bildungsprogrammen sind einen wichtigen Teil des rumänischen Bildungssystems.In meinem Studium, habe ich die folgende Hypothese getestet und auch validiert: die Bedarfsermittlung sowie die zur Verfügung gestellten Fort- und Weiterbildungsangebote, die unterstützend für die Entwicklung der beruflichen und fachlichen Kompetenzen fungieren sollen, gelten als eine sehr wichtige Vorraussetzung, um die angezielte Qualität der Bildung in Bezug auf das Lernen und berufliche Entwicklung, zu gewährleisten.

Die Methoden und Werkzeuge, die ich in der Forschung verwendet habe, sind sowohl qualitative als auch quantitative und basieren auf einer Mehrzahl von Fragebögen, Einzelinterviews und Fokusgruppen.

Ich habe mich für diese Art von Verfahren entschieden, da es mittels diesen standardisierten Fragebögen, die Probanden nicht die Möglichkeit hatten, bestimmte Entscheidungen oder Meinungen, zu erklären.

Die quantitative Studie wurde an einer nicht-probabilistische Stichprobe von 770 Lehrern durchgeführt und die Fokusgruppen wurden mit 10 Befragten durchgeführt, die zufällig von den Teilnehmern an der Ausbildung ausgewählt wurden.

Alle partizipierende Lehrer, waren Teil der Bachelor-Ausbildung in Rumänien und sie haben an Trainingsprogramme teilgenommen, die von der Abteilung Erziehungswissenschaften der Fakultät für Psychologie und Erziehungswissenschaften akkreditiert wurden.

\section{Introduction}

Identifying training needs and offering follow-up courses is a key condition for recording the success of a lifelong learning program. Educational requirements imply the training and development of professional competencies appropriate to the teaching profession standards. Thus, the need to develop the level of training and qualification/retraining, self-education, selfdevelopment and maximization of the skills and the individual intellectual potential is a desirable dimension of educators, educated and trainers alike. This study investigates both the need for in-service teacher education from the pre-university environment and the value indicators of the training programs needed to reach the quality standards in education. Achieving professional competencies consistent with current psycho-pedagogical and social exigencies is desirable given the relationship of interdependence between the quality of education and the quality of the teaching staff, hence the need to ensure 
continuous training on the basis of rigorous standards correlated with international standards.

When we designed this program, we focused on the characteristics of the beneficiaries, i.e. on the need to develop specific content management and communication in educational institutions. We have left from the results of studies that have investigated adult training, according to which trainers teach in a declarative way, and learners must transform declarative knowledge into procedural knowledge, possibly only if they have procedural knowledge, that is, they are capable of carrying out certain tasks and acting accordingly (Stolovitch, Keeps \& Rosenberg, 2017).

In developing the training program, we have ensured that our beneficiaries have the cognitive and motivational framework in place, so that we have created relevant course support, we have provided learning activities based on their experience, we have organized moments that offer the opportunity for collaborative learning and situations in which I suggested the advantages of participating in programs that unconditionally support their professional development.

\section{The National and European Context of Professional Learning and Development (PLD)}

In Romania's educational system, continuous training is achieved through the acquisition of didactic degrees, but also through participation in various programs of continuous training. Regarding continuous training, the Law on National Education in Romania (LEN, 2011) states that it includes professional development and career development and is based on progress in the field of education and training. Consequently, the management of each educational unit designates a person responsible for the continuous improvement / training of teachers, who will manage the following coordinates: information, organization, counseling - consulting, training, monitoring and appraisal.

Continuous training and professional development programs, initiated and carried out by universities or various associations and organizations, are a real benefit in professional development. This is represented by the educational offer of a provider, which aims at the formation and development of the professional competences of the didactic and auxiliary teaching staff, as well as of the leadership, guidance and control personnel in the pre-university education, according to the professional standards for didactic profession, standards quality and professional skills according to art. 2, par. (2) of OMECTS no. 5564/2011.

Continuous training of teaching, leadership, mentoring and control staff and professional retraining are based on professional standards for teaching, quality standards and professional skills.

Although the complexity of the teaching profession requires a lifelong learning perspective in order to adapt to rapid change and evolving constraints or needs, international studies on teachers and PLD have shown that up to now vocational training is considered a professional duty in approximately half of all European states, but it is practically optional in many of them. Depending on the degree of centralization / decentralization in national education systems, PLD planning and organization is the responsibility of schools or local authorities in a number of countries (including the Netherlands, the UK and Ireland, and most of the Nordic and East European countries).

An organized plan of supportive measures for new teachers in their early years of career - the most demanding and decisive stage in teacher development - is only foreseen in a small group of EU countries, of which the United Kingdom, Luxembourg and Lithuania seem to have a wide range of support activities (Caena, 2011).

In 2013, the Education, Audiovisual and Culture Executive Agency (EACEA, Eurydice and Policy Support) published the results of a study on key data on teachers and school leaders in Europe. According to this study, Professional Learning and Development has gained considerable importance in recent years, being now considered a professional duty in 28 education systems. Usually, this obligation is mentioned in legislation or regulations in some countries and is stipulated in the employment contracts of teachers or in collective agreements. Thus, in six countries, the minimum number of hours each teacher is obliged to dedicate to PLD courses (Luxembourg, Hungary, Malta, Portugal, Romania and Finland) is stipulated.

In the Netherlands, Slovenia and the United Kingdom (Scotland), a minimum number of hours dedicated to professional development is considered as a teacher's right. In Denmark, Ireland, Greece, France, the Netherlands, Poland, Sweden, Iceland and Norway, the involvement of teachers in professional development is 
not expressed in terms of professional duty. However, in France and Poland, development is clearly linked to career progression. In all other education systems, even if development is not explicitly required for promotion, this is an important advantage.

Professional development and progress in teaching is also related to the motivation of the teaching staff. Thus, in 18 European education systems, participation in PLD is clearly linked to promotion to a higher professional level that entails wage increases. However, professional development is rarely the only condition for advancement, generally being an important aspect in evaluating the performance of teachers.

Even if there are concerns about PLD at European level, many studies being developed, it is difficult to identify their pragmatic effects. In some situations, the professionalism of the teaching profession is reformed in a disparate way in the sense that either reforming the initial training or the component of the continuous professional development, or the period of the professional traineeship, results in a lack of continuity and coordination between the three parts of the professionalization (Catalano, 2018).

PLD is essential to ensure that teachers keep up with the changes in education, familiarize themselves with the new teaching methods in the areas of content they teach, learn the latest digital teaching methods and adapt to the needs of new generations students. However, despite the national recognition of the importance of PLD for teachers, report after report describes that PLD is inadequate (Lawless, Pellegrino, 2007).

Economic and social changes penetrate quickly and inevitably in every social field, including education (Hargreaves, 2000; Webb et al., 2004). Thus, teachers who want to cope with a wide range of tasks and requirements in such a context are confronted with the need to define and redefine their professionalism and professional development (Esteve,2000; Hargreaves, 2000). Thus, teachers have to develop professionally throughout their careers, due to constant changes in educational policies, but also due to innovations in the field of education (Knight, 2002).

This pathway is called lifelong learning or continuing professional development (PLD) and is considered a key factor for improving the quality of teachers, schools, and the role teachers have on pupil learning (Day \& al., 2007).
The term PLD is used to describe all the activities in which teachers engage in a career and improve their didactic activity (Day \& Sachs, 2004). PLD activities can include professional development meetings, internal and external courses and conferences, coaching and mentoring activities, participation in reflexive discussions and research-action (Sabah, Fayez, Alshamrani, Mansour, 2013).

Vocational training is a process by which people are helped to learn a skill (manual or intellectual) or a method, and the factors that influence the quantity and quality of training activities are:

- Amplitude of changes in the external environment;

- Internal changes;

- Existence of appropriate skills and qualifications in the workforce;

- The degree of adaptability of the workforce;

- The extent to which the organization supports the idea of internal career development, etc. (Florea, 2014, p. 3638).

Guskey (2002), Ifanti \& Fotopoulopou (2011) argue that high quality professional development is a central component in almost all modern strategies to improve education. Policy makers increasingly recognize that schools cannot be better than teachers and administrators working within them.

Eraut (1994) states that it is not only important to acquire a type of professional knowledge but the context in which it is acquired and used later to help us understand the process of acquiring them. Analyzing the means by which the PLD is organized and structured, we can highlight not only the motivation behind this process but also the nature of the professional knowledge and professionalism itself.

The most common PLD models are consistent with the core standards of the teaching function and the competencies associated with nationally agreed standards that unfortunately maintain a high level of centralized control and maintain a limitation of innovation and creativity in teaching. Standardization limits proactive action in identifying and meeting their own PLD needs (Kennedy, 2005).

Professionalization involves the legitimation of the teaching profession among socio-human activities and professions by recognizing the role of teachers in 
promoting individual, social and European values and by shaping a unitary model of the teaching profession based on professional standards, differentiated according to age at department and specialization (Catalano, 2015, 2016).

In terms of lifelong learning programs, John Hattie, a researcher in the field of visible learning, believes that they 'need to deal less with the promotion of a variety of teaching strategies and more with how the beginner teachers can assess the impact of their teaching on students ' $(2014$, p. 179).The quality of the educational process is influenced by the construction of the professional identity of the future professor, by the way he perceives and realizes the responsibilities claimed by the teaching profession.

Ken Robinson, the well-known British expert on education and teaching, gives us a coherent view of the teaching career: "The extraordinary teachers are the heart of the extraordinary schools. Through their different roles, they can accomplish three essential goals for students:

- Inspiration: They inspire students with their own passion for their disciplines and to achieve the highest level in their fields.

- Trust: They help students to assimilate the skills and knowledge they need to become independent learners, with confidence and who can continue to develop their level of understanding and expertise.

- Creativity: They allow their pupils to experiment, explore, ask questions and develop their skills and provisions of original thinking. These benefits should be derived from the whole process of training for all the subjects in the program" (Robinson \& Aronica, 2015, p. 188).

Professional Learning and Development refers to the training activities carried out in formal and non-formal environments, distinct in their essence, which can be ordered on an axis, depending on the distance from the requirement to solve the nonconformities and the consequences of the results of the evaluation and selfevaluation processes.

A good PLD strategy should start from teacher evaluation. This would give usefulness to the results of the evaluation, which would reveal the possible discrepancies between the requirements of the evaluation standards and the level of the teachers' performance. Current PLD strategies of nationally-designed teachers need functional quality management systems at school level for effective program implementation. We appreciate the effort made by the Romanian Agency for Quality Assurance in Preuniversity Education (ARACIP), a public institution of central interest, in the development of management and quality assurance systems in education, through the European strategic projects in which this institution is engaged.

Professional development implies setting goals centered on self-knowledge, self-assessment and the development of career planning skills, and career progression involves monitoring their degree of accomplishment. However, research confirms, based on teachers' own statements, that there is insufficient awareness of the need for PLD, as this does not guarantee a change in the practices teachers adopt in classroom work (Harland \& Kinder, 1997).

\section{Methodology and study results}

In the course of the study we used a mixed research methodology, on the one hand a questionnaire survey, as a quantitative method, cross-centered with the focus group method, as a qualitative method. The rationale for which we have used both research approaches has circumscribed the testing and validation of the hypothesis that provision of continuous training programs whose content has been selected following the identification of real needs of trainers and value-specific indicators of professional development contributes significantly to the formation of professional competencies and strengthening the professional status of teachers.

The present study was administered to a sample of 770 $(\mathrm{N}=770)$ respondents for the quantitative methodological approach and 20 groups of 10 teachers, selected on the basis of their own options for participation in the qualitative investigation conducted by the focus group method and supervised by us.

It should be noted that the sample was made up of the teachers who participated and finalized the continuous training programs provided by the Department of Educational Sciences and the questionnaires were administered after the appraisal of the students. Also, the focus group meetings were organized during the training program and pre-validated the application of the questionnaire, as the focus group structure was circumscribed to the questions and the research hypothesis. 
In the design and deployment of training programs, I have used innovative ways of teaching, as well as various opportunities to interact with colleagues and trainers. The design decision was framed by teacher-centered professional development ideas that allow teachers to access resources and tools to design their own learning experiences.

In a similar study, only that it targeted the online PLD component, Farooq, Schank, Harris, Fusco and Schlager (2007) used a methodology to immediately identify the perceived value of the components and design content of the programs, as well as evaluate learner satisfaction.

Vavasseur and MacGregor (2008) have expanded the idea of technical design of training programs using mixed methods in which they blended content-oriented online learning with face-to-face training. Among the advantages that have been learned are the importance of face-to-face training, teachers' collaboration in team building, more concrete content in traditional training than online training.

The main categories of professional development goals that emerged from the review of the literature were taken into account by us both in building the questionnaire and structuring the interview guide we used in the focus group method.

The questionnaires we have applied are likely to fit into statistically significant samples, allowing a rapid interpretation of the results, which can be administered to numerous groups, as was the case, and the interviewer's perceptions of anonymity were high. There is also a relatively high validity of the calculation of the results for the well-built questionnaires, the close-ended being able to provide the exact information desired by the researcher (data analysis is easier for closed items).

Organizing and conducting focus group meetings on the basis of the interview guide whose variables we recall in this study provided us with detailed information, respondents using their own words about the real perception of lifelong learning: attitudes towards their own professional status, satisfaction with the professional environment, perception of their own professional skills, attitudes towards continuous training, their own conception of continuous training, the frequency of access to training courses, the share of reasons for nonparticipation in continuous training, the share of the courses access to training, the share of expectations for future training areas, the share of the need to develop professional skills, the perception of the expected characteristics of continuous training courses, the perception of the valency of continuing training.

We consider that the sample of subjects is valid given that the participants in the training programs offered by us have been subject to the approval of the Board of Governors of the schools at the proposal of the responsible person in charge of the continuous training in each school. Thus, their selection was based on professional arguments based on the real need for continuous training.

In addition to the results obtained from the application of the questionnaire (the processing and interpretation of the data obtained after its application was made through the SPSS program one of the most used in the statistical analysis of the data), the focus group was trying to capture not only the opinions of those surveyed, but also their motivations, attitudes and expectations towards the need for PLD.

In the first part of the questionnaire we were concerned with the basic variables, namely: didactic function and didactic experience. In the second part of the questionnaire, we introduced 8 multiple choice items through which we wanted to identify teachers' perceptions of PLD.

Table no. 1 provides details about the participants' job positions and their seniority in education which, according to the table below, indicates a standard deviation of 10.68 and an average of 17.83 years old which allows us to affirm that this statistical population renders enough homogeneity.

We notice that teachers who are in primary didactic positions represent the majority, those who teach various subjects in secondary school and high school have a share of about $30 \%$ and those in pre-school education about $20 \%$. Although this dispersion is in favor of the teaching staff in primary education, we do not consider that research results can be prejudiced in any way. 
Table 1. Distribution of respondents on teaching and teaching experience

\begin{tabular}{llll}
\hline & Frequency & Percent \\
\hline \multicolumn{2}{l}{ Teacher in secondary school and high school } & 230 & 29.87 \\
\hline \multicolumn{2}{l}{ Primary school teacher } & 380 & 49.35 \\
\hline \multicolumn{2}{l}{$\begin{array}{l}\text { Teacher of pre-school education } \\
\text { Total }\end{array}$} & 160 & 20.78 \\
\hline $\mathbf{N}$ & Min & 770 & 100.00 \\
\hline 770 & Max & Average & Standard deviation \\
\hline
\end{tabular}

Maxwell (1996) is of the opinion that research methodology should have a coherent design in which research components are compatible and relate to research questions. In elaborating the research questionnaire and methodology we took into account the following points:

- clear research questions;

- rigorous data collection methods, quantitative and qualitative, that have been linked to research questions;

- analyzes based on research questions;

- findings resulting from the analysis of research questions (Dede, Ketelhut, Whitehouse, Breit \& McCloskey, 2009).

We have identified in the literature a number of articles that have analyzed the impact of training programs on the PLD, so we have formed an updated picture of the empirical research on PLD, we have discussed some of the most recent studies that meet and also our research criteria.

We have evaluated these research studies and found that the research questions addressed the issues that we will also describe below. It is true that these studies are not exhaustive, but they are the best steps to differentiate between the different types of studies we have reviewed in order to form the most appropriate image for our analysis.

We present the research questions that have been formulated, the results that have been obtained and a comparison, where this is appropriate, with the results identified in the studies analyzed by us in the literature. We also need to specify that PLD specific to Romania is not the same in the other states around the world, so some interpretations of the results obtained could be difficult to generalize.

Table 2. Need for training domains

\begin{tabular}{lcc}
\hline & Frequency & Percent \\
\hline Courses offered by the Teaching Staff House (CCD) & 320 & 41.56 \\
\hline $\begin{array}{l}\text { Courses offered by the Department for Teacher Training (DPPD) at } \\
\text { universities }\end{array}$ & 210 & 27.27 \\
\hline
\end{tabular}

\begin{tabular}{llll}
\hline Courses conducted through Sectoral Operational Programs. Human & 170 & 22.08
\end{tabular}

Resources Development (POSDRU), offered by different institutions

\begin{tabular}{lcc}
\hline Courses offered by NGOs & 70 & 9.09 \\
\hline Total & 770 & 100.00
\end{tabular}

Respondents' responses to the typology of in-service training providers are outlined in table no. 2 and we notice that the highest attractiveness is related to the continuous training programs offered by the Teaching Staff House $(41,56 \%)$, the second place with a $27,27 \%$, the
Departments of Teaching Staff Training at the Universities, while the courses conducted through POSDRU occupy the third position according to the respondents' preferences. The argument for which most respondents chose to follow the training programs provided by the CCD is related to the obvious visibility 
that this institution has, being subordinated to the school inspectorates and in direct connection with school managers in the public educational system.

A series of studies (Goodall et al., 2005, Harris et al., 2006), which tackled the competencies of the trainers and the experience of the PLD provider, concluded that as concerns their choices, teachers have a critical role in choosing an offer that is directly linked to the performance of the PLD provider. The provider of a PLD program needs to consider a number of key factors, including teacher motivation, wishes and expectations (Sabah, Fayez, Alshamrani, Mansour, 2013). Table no. 3 below presents teachers' options for different types of areas of interest that reflect their need for training.

Table 3. Need for training domains

\begin{tabular}{lcc}
\hline & Frequency & Percent \\
\hline Teaching practice specialty & 90 & 11.69 \\
\hline Specialty subject matters- specific to the post / function held & 220 & 28.57 \\
\hline Elements of Group / Class Management & 80 & 10.39 \\
\hline Computerized / digital systems & 150 & 19.48 \\
\hline Innovative elements in teaching-learning-appraisal approaches & 230 & 29.87 \\
\hline Total & & 100.00
\end{tabular}

As regards the specific training needs, respondents perceive that the elements that contribute to the innovation of the didactic process, as well as those related to the specific teaching domain are of paramount importance. Although the digital era is 'overwhelming' the daily activity, digital needs are third in attractiveness, and knowledge of specialty didactics and classroom management elements are perceived as necessary but not prioritized.

Table 4. Types of training activities

\begin{tabular}{lll}
\hline & Frequency & Percent \\
\hline Face-to-face training & 470 & 61.04 \\
\hline On-line training & 90 & 11.69 \\
\hline Blended-learning training & 210 & 27.27 \\
\hline Total & 770 & 100.00 \\
\hline
\end{tabular}


Table number 4 indicates the willingness of the teachers to take part in face-to-face training programs, even if the digital era with its new technologies has infused greatly the didactic process. However, $27.27 \%$ of respondents adhere to the organization of blended-learning training programs, seen as a mix between traditional and innovative organization. Researchers argue that PLD courses that call for technology use play a major role in helping teachers to learn better about how to integrate it into future practice by facilitating the learning process (Collier, Weinburgh \& Rivera, 2004; Truesdell, \& Birch, 2013).

Otero, V., Peressini, D., Meymaris, KA, Ford, P., Garvin, T., Harlow, D., Mears, C. (2005) have observed a significant change not only in individual practices but also in understanding how technology can be used for didactic purposes. Similarly, Hooper and Riber (1995) have proposed a model for the adoption of new technologies that consists of specific phases: familiarization, use, integration, reorientation and evolution. In the familiarization phase, the teacher simply learns to use technology. In the use phase, the teacher uses technology in the classroom, but has little understanding or knowledge about technology as a pedagogic and learning

tool. During the integration phase, technology becomes an integral part of the course in terms of delivery, learning, management or other aspect of the class. In the reorientation phase, the teacher uses technology as a tool to facilitate reconsideration of the purpose and function of the class. Finally, teachers entering the evolution phase are able to continuously modify the structure and pedagogy of the class to include learning theories, technologies and lessons learned from experience.

Table 5. Ways of presenting the courses' content

\begin{tabular}{lll}
\hline & Frequency & Percent \\
\hline Detailed & 60 & 7.79 \\
\hline Synthesized, highlighting concepts / key elements / events & 280 & 36.36 \\
\hline Particularly, by case studies & 190 & 24.68 \\
\hline Evoking pragmatic experiences and solutions & 240 & 31.17 \\
\hline Total & 770 & 100.00 \\
\hline
\end{tabular}

In order to improve our teaching experiences as trainers, we wanted to probe the learners' opinion about how to submit the curriculum specific to the training program. As can be seen in table no. 5 the most preferred way is to summarize the information by highlighting the key concepts, followed by the exploration of experiential learning and pragmatic solutions as an option while the particularisation of the contents and the discussion of case studies represented the third option of the respondents

Table 6. Respondents' options regarding the most effective way to run PLD courses

\begin{tabular}{lcc}
\hline & Frequency & Percent \\
\hline Interactive & 450 & 58.44 \\
\hline Lecture type & 40 & 5.19 \\
\hline Through demonstrations and exercises & 280 & 36.36 \\
\hline
\end{tabular}


In table number 6 are listed the respondents' options regarding the most agreed modalities for the transmission of the content specific to training programs. The most agreeable way is the interactive one with a score of $58.44 \%$, and demonstration and implementation of applied exercises is perceived as the most effective strategy by
$36.36 \%$ of the participants in our research. Only 4 of the 770 respondents chose the lecture as the main method, which suggests that traditionalist approaches have lost their meaning compared to innovative and interactive approaches.

Table 7. Respondent's' opinion regarding the right way for the assessment method they prefer for training courses

\begin{tabular}{lll}
\hline & Frequency & Percent \\
\hline Portfolio evaluation & 510 & 66.23 \\
\hline Oral evaluation - oral questionnaire & 50 & 6.49 \\
\hline Oral evaluation - presentation of completed themes & 90 & 11.69 \\
\hline Interactive debate based on a material (project) drawn up by student groups & 120 & 15.58 \\
\hline Total & 770 & 100.00 \\
\hline
\end{tabular}

Evaluation seen as a basic component of in-service teacher education programs is often the subject of discussions as regards the effectiveness of these forms of continuous training. Thus, we have inserted in the questionnaire included in the present investigation an item where we asked the respondents to express their option for the most efficient evaluation method for the courses they had during the continuous training program. Table no. 7 indicates that the most preferred method, with a significant percentage of $66.23 \%$, i.e. 51 respondents out of the 770, was portfolio evaluation. The method of interactive discussion based on a project won't be neglected in our academic work, as $15.58 \%$ of the respondents opted for such an alternative in the final assessment of lifelong learning programs. The methods of oral evaluation constructed as oral questionnaires or presentations were less well accepted. 


\begin{tabular}{llc}
\hline & Frequency & Percent \\
\hline Practical aspects & 380 & 49.35 \\
\hline Identifying issues and solutions & 190 & 24.68 \\
\hline Reflections and personal investigations & 10 & 1.30 \\
\hline Putting theory into relationship with practical experience & 190 & 24.68 \\
\hline Total & 770 & 100.00 \\
\hline
\end{tabular}

In order to improve our work in the field of continuous training we asked the teachers participating in the investigation to appreciate which ways would suit their training needs. Table no. 8 indicates that a priority is to transfer the practical experiences specific to the didactic activities, then, an equal focus has been placed on the identification of problems and solutions, as well as the relationship between theory and practical reflections.
What is interesting for us is that, although we wanted to challenge respondents with a variable aiming at triggering a metacognitive behavior related to triggering personal reflections and introspections, only one respondent agreed with this way of focusing on teaching the curriculum of the training program.

In order to acquire cross-curricular skills, training courses would help you if:

Table number 9. Respondents' opinion versus acquiring cross-curricular skills

\begin{tabular}{lcc}
\hline & Frequency & Percent \\
\hline Focus on cooperative learning & 410 & 53.25 \\
\hline Highlight self-learning strategies and behavioral self-regulation & 160 & 20.78 \\
\hline $\begin{array}{l}\text { Present operating models with scientific content (synthesis-generalization, } \\
\text { analysis-comparison, etc.) }\end{array}$ & 200 & 25.97 \\
\hline Total & 770 & 100.00
\end{tabular}

Starting from the premise that PLD ensures the updating, development and extension of the transversal competences of the teaching staff, we have put in the questionnaire an item asking the respondents to express their choice. We can see in table no. 9 that $53.25 \%$ of the respondents were interested in adopting training strategies through co-operation, an attitude that is specific to adult education. Operating with scientific content was attractive for $25.97 \%$ of the sample surveyed, and only $20.78 \%$ of the respondents agreed to self-learning strategies and behavioral self-regulation in order to build transversal competencies through training programs. 
To develop expertise in a field, learners should benefit from learning experiences that enhance their ability to recognize information models that are meaningful to solve problems in this area (Bransford et al., 1999). This will not be possible if learning tasks are simplified or detached from actual teaching contexts.

In the course of the diagnosis conducted, besides the questionnaire survey method, we also used a focus group as a qualitative method. Through this method, we obtained fewer concrete data, but it was more useful in terms of sincerity and objectivity. Through this method, we also had the opportunity to observe participants' non-verbal behavior, gestures, emotions, all of which provided us with additional information that supported verbal responses.

In this study, the qualitative intervention was guided by a series of variables that underpin the elaboration of the focus group guide. These were the following:

- Teachers' expectations for in-service training programs as indicators: the quality of the program, the quality of available human and material resources, access to training programs, duration of courses, etc.;

- Suggestions for improving the curriculum of the program, as well as indicating efficient ways of methodological approach (the theory-practice relationship within the training programs, the usefulness and applicability of acquired knowledge and skills);

- Appreciation of strategies, methodologies for evaluation and accreditation of training programs;

- The ways of promoting the training offer;

- The usefulness of in-service training programs in didactic activity;

- Difficulties encountered in organizing and conducting training programs (lack of motivation, lack of budgets for human resource training, etc.);

- Proposals for solutions and recommendations on improving training programs.

Based on the variables listed above, we explored the responses of the respondents presented openly in the focus group. Thus, we have found that the basis of the decision regarding the options they take regarding the continuous professional training consist in a series of arguments that mention:

- acquiring new professional, scientific and transversal skills;
- increasing personal motivation for participation in training;

- improving the efficiency of teaching activity;

- enhancement of school time management;

- the motivation for continuing vocational training is rather extrinsic than intrinsic;

- discovery of new methodologies with an interactive and innovative character.

When we examined the expectations, the agreement or the disagreement with the PLD, based on the grid variables, the views showed that, as a whole, older teachers were more likely to have a negative view of PLD. Data on individual affirmations showed that most teachers believe that the school's PLD needs must be ahead of their individual needs. The results obtained by us have also been validated in other investigative approaches to the perception of teachers towards PLD (Hustler, Mc Namara, Jarvis, London, Campbell \& Howson, 2003).

The effectiveness of PLD experiences can therefore, to a large extent, be a consequence of the learning context, be it the culture of a PLD course, or the educational culture of the school and the professional reference group. Values, attitudes, interactive practices in the context of learning can have a great influence on the performance of the teacher, as well as on professional culture (Dadds, 1997).

\section{Study boundaries}

Opinion questions comprise aspects that highlight the perception of each individual taking part in the investigation, given by their inner universe, that is why sometimes these items imply difficulties in the accuracy of the answers given, the consistency between real views and those expressed by good or bad true answers or false answers.

Another limitation can be attributed to the limited sample of teachers compared to the large number of preuniversity education teachers in Romania.

As part of the focus group approach, we have been unable to ensure confidentiality, and this may induce compliance or self-censorship in participants' responses. Usually respondents show a desire to be socially accepted and feel the need to be perceived as 'in the world ', classical experiments show that sometimes it is enough for someone to have only one ally to talk about experiences or 
opinions contrary to those already expressed (Carey \& Smith, 1994).

Another limit of our study consists in the time needed for evaluating PLD programs. Currently, most of the data is collected immediately after the end of a program or even during the course of the program, and teachers actually apply what they learn in professional development after a month or several months in the teaching process, so that the impact of the acquisitions made by teachers by participating in PLD programs may diminish. In this regard, we want to carry out a rebound / distance assessment to test the usefulness of the abolished aspects of medium and long-term programs.

Dede, Ketelhut, Whitehouse, Breit \& McCloskey (2009) note that the more and varied the evaluations, the more likely it is to more fully perceive PLD purchases and how new knowledge and skills are used by teachers in teaching.

\section{Conclusions and discussions}

The didactic career is double-dimensional, on the one hand, the objective side which implies the development and progress of the teaching staff and, on the other hand, the subjective side which represents the proper professional path, consisting of the assumption of a very complex ensemble of knowledge, skills, aspirations and individual motivations, relative to the requirements of the educational system.

Although at European level there are concerns about the professional development of teachers, many studies have been developed even though it is difficult to identify their pragmatic effects.

Most of the time, trainees are poorly motivated to take part in different PLD initiatives, as their training is not rewarded by wage increases, and participation fees in lifelong learning programs are paied from their personal budget. Increasingly, more and more teachers are participating in training courses and more and more programs and suppliers contribute to the diversification of offers, which is very diverse.

Teachers' perceptions of PLD have been positively influenced by their ability to strengthen and innovate the teaching and learning process itself. These findings were in line with Day \& Gu (2007) and Ifanti \& Fotopoulopou (2011), which supported the importance of these factors in the professional satisfaction of teachers. With regard to the first and most important factor for increasing teacher satisfaction, improving the teaching strategies of a considerable part of our sample correlated their professional development and desire to become better teachers with the learning outcomes of their pupils. Such a finding is also in line with the studies of Guskey (2002), Helsby and McCulloch (1996).

The teachers in our sample mentioned that they have invested their personal time in PLD in order to keep up with professional requirements and responsibilities. This finding is consistent with Hustler, Mc Namara, Jarvis, London, Campbell \& Howson (2003).

It should be noted that the perception of PLD teachers is also influenced by a number of negative connotations that induce negative emotions and professional stress. Thus, inadequate labor conditions specific to Romania (commuting between home and work, low wages), the high number of pupils in classes (sometimes over 30), the bureaucratic system requiring multiple procedures, statistics and documents, parental pressure and multiple assessments may lead to teachers' lack of motivation and professional satisfaction. Similar findings are also reported in Day's et al. (2007), Zembylas (2003) and Ifanti \& Fotopoulopou (2011), which present the results of a similar research in Greece that resembles our results.

There are other factors that influence PLD in the view of our respondents, such as personal, environmental, and cultural contexts. Thus, according to these, there are similarities and differences of perception as concerns the items in the questionnaire and the variables in the guide of the focus group method. Overall, these similarities and differences show how teachers perceive the abovementioned concepts as well as the factors that affect their ideas. Dadds (1997) considers that the core of PLD should be the cultivation of intrinsic motivation and critical judgment in relation to the development of the self, seen as crucial and indispensable from the perspective of didactic activity. However, even the longest PLD course is short compared to the uninterrupted learning required for professional development.

In conclusion, the teachers in our sample considered PLD as a very complex multidimensional process and stressed the importance of having more knowledge, skills and competencies that will substantially contribute to the consolidation of their professional status. These ideas are 
in line with other relevant findings of some of our researches (Ifanti \& Fotopoulopou, 2011) and highlight the shared concerns of PLD teachers in several European countries.

This research has reconfirmed that PLD is a particularly complex phenomenon with individual, organizational, conjunctural or systemic determinations and influences.

Some longitudinal research on PLD's goal showed that most of the teachers who participated in different PLD courses do not put into practice what they have learned even if the results of the evaluation were positive (Iain, 2011). Thus, in order to be effective, PLD activities need to be designed and distributed appropriately to meet the professional development needs of teachers. The specialized literature on PLD's effectiveness clearly indicates that it should be designed around meaningful learning activities (Iain, 2011; Adams, 2005; Chalmers \& Keown, 2006; Dede, Ketelhut, Whitehouse, Breit \& McCloskey, 2009, Gosha, Billionniere, Gilbert, \& Ramsey, 2010; Meehan, Obler, Schiorring, \& Serban, 2002; Mouza, 2009; Ostashewski, 2010; Samarawickrema, Stacey, \& Warren, 2008; Wettasinghe, 2003). This means that training modules must be related to practical situations and practical challenges, and that training should focus on pedagogical innovation that will lead to improved student learning (Meehan et al., 2002).

A very high-quality research approach should be based on previous research, but also on research in other areas, such as law or medicine, to consider expanding research design and online PLD programs. We believe that this type of research will lead to a general concept that integrates theory and practice based on evidence. Building such a comprehensive theory involves a collaborative effort between specialists from different scientific fields.

\section{Authors note:}

Horațiu Catalano is Associate Professor at the Faculty of Psychology and Sciences of Education (Babeş-Bolyai University, Cluj Napoca, Romania) in the Department of Educational Sciences. His research and teaching areas are focused on Early Childhood Education, Teaching Process, Pedagogy of Play, Continuous Professional Development etc. During his professional career, he published an important number of studies in national and international volumes. He coordinated a series of volumes concerning teachers' professional development, educational alternatives and |pedagogy of play.

Ion Albulescu is habilitated Professor and Ph.D. Coordinator at the Faculty of Psychology and Sciences of Education (Babeş-Bolyai University, ClujNapoca, Romania) Department of Educational Sciences, Faculty of Psychology and Educational Sciences. His research interest is reflected in a series of studies, articles and books published by prestigious international and national editors. The Professor Albulescu teaching and research area covers several educational domains such as Educational Alternatives, Comparative Education, Pedagogical Theories and History of Educational Thinking etc.

Cristian Stan is habilitated Professor and Ph.D., Department of Educational Sciences, Faculty of Psychology and Educational Sciences (Babeş-Bolyai University, Cluj-Napoca) and Director of the Doctoral School Education, Reflection, Development. His research area covers several educational domains such as Theory of education, Theory and practice of didactic evaluation, Intercultural education, Didactic communication, etc.

\section{References}

Adams, S.T. (2005). A strategy for technology training as part of a masters program conducted at a school site. Journal of Technology and Teacher Education, 13(3), 493-514.

Carey, M.A., \& Smith, M.W. (1994). Capturing the Group Effect in Focus Groups: A Special Concern in Analysis. Qualitative Health Research, 4(1), 123-127. Available form: https://doi.org/10.1177/104973239400400108/ [AccessedFebruary2020].

Bransford, J.D., Brown, A.L., \& Cocking, R.R. (1999). How people learn: Brain, mind, experience and school. Available from http://books.nap.edu/openbook.php?record_id=6160\&page=R1. [Accessed20May2019].

Caena, F. (2011). Literature review Quality in Teachers' continuing professional development, Working paper for Education and Training 2020 Thematic Working Group 'Professional Development of Teachers'/online/. Available from: eu/education/school-education/doc/quality_en.pdf.

/[Accessed20May2019].

Catalano, H. (2015). Role of Mentoring in Professionalization for Teaching Career, in Perspectives for Research in Education, Editor: Simona Sava, University Publishing House, Bucharest.

Catalano, H. (2016). Professional Development and Progression in Educational Career - Ascertaining Study, The European Proceedings of Social \& Behavioural Sciences, published by Medimond Monduzzi Proceedings Divison, Editori: Antonio Sandu, Ana Frunză, Gabriel Gorghiu, Emilian Ciongaru, 8589. 
Catalano, H. (2018). Procesul de învățământ: direcții epistemice, pragmatice și experiențiale. București: Editura Didactică și Pedagogică.

Chalmers, L., \& Keown, P. (2006). Communities of practice and professional development. International Journal of Lifelong Education, 25(2), p. 139-156.

Collier, S., Weinburgh, M. H., \& Rivera, M. (2004). Infusing technology skills into a teacher education program: Change in students' knowledge about and use of technology. Journal of Technology and Teacher Education, 12(3),447-468.

Dadds, M. (1997). Continuing professional development: nurturing the expert within. Journal of In-Service Education, 23:1, 31-38, Available from: DOI: https://10.1080/13674589700200007.

Day, C., Sachs, J. (2004). Professionalism, Performativity and Empowerment: Discourses in the Politics, Policies and Purposes of Continuing Professional Development. In C. Day, \& J. Sachs (Eds.), International Handbook on the Continuing Professional Development of Teachers, 3-32, Maidenhead: Open University Press.

Day, C., \& Gu, Q. (2007). Variations in the conditions for teachers' professional learning and development: Sustaining commitment and effectiveness over a career. Oxford Review of Education, 33 (4), 423-443, Available from: http://dx.doi.org/10.1080/03054980701450746.

Day, C., Flores, M.A. \& Viana, I. (2007). Effects of national policies on teachers' sense of professionalism: Findings from an empirical study in Portugal and in England. European Journal of Teacher Education, 30 (3), 249-265, https://doi.org/10.1080/02619760701486092.

Dede, C., Ketelhut, D.J., Whitehouse, P., Breit, L. \& McCloskey, E.M. (2009). A Research Agenda for Online Teacher Professional Development. Journal of Teacher Education, 60(1), 8-19. Available from: https://doi.org/10.1177/0022487108327554.

Esteve, J.M. (2000). The transformation of the teachers' role at the end of the twentieth century. New challenges for the future. Educational Review, 52 (2), 197-207.

Eraut, M. (1994). Developing Professional Knowledge and Competence. London: Falmer Press.

Farooq, U., Schank, P., Harris, A., Fusco, J., \& Schlager, M. (2007). Sustaining a community computing infrastructure for online teacher professional development: A case study of designing tapped in Computer Supported Cooperative Work. The Journal of Collaborative Computing, 16(4/5), 397-429.

Florea, N.V. (2014). Training, coaching, mentoring. Metode și modele. București: Editura C.H. Beck.

Goodall, J., Day, C., Lindsay, G., Muijs, D., \& Harris, A. (2005). Evaluating the Impact of Continuing Professional Development. Department for Education. Available from: https://doi.org/10.4236/ojn.2017.78069.

Gosha, K., Billionniere, E., Gilbert, J. \& Ramsey, M. (2010). Developing a Framework for Teacher Professional Development Using Online Social Networks. In D. Gibson \& B. Dodge (Eds.), Proceedings of Society for Information Technology \& Teacher Education International Conference 2010 (pp. 1449-1454). Chesapeake, VA: AACE.

Guskey, T.R. (2002). Professional development and teacher change. Teachers and Teaching: Theory and Practice, 8 (3/4), 381-391, http://dx.doi.org/10.1080/135406002100000512.
Hargreaves, A. (2000). Four ages of professionalism and professional learning. Teachers and Teaching: Theory and Practice, 6 (2), 151-182, http://dx.doi.org/10.1080/713698714.

Harris, A., Day, C., Goodal, J., Lindsay, G., Muijs, D. (2006). What difference does it make? Evaluating the impact of continuing professional development in schools. Scottish Educational Review, 37, 90-98.

Hattie, J. (2014). Visible Learning. Teacher's Guide, Trei Bucharest: Publishing House.

Harland, J. \& Kinder, K. (1997). Teachers' continuing professional development: framing a model of outcomes. British Journal of In-service Education, 23:1, 71-84, https://doi.org/10.1080/13674589700200005.

Helsby, G., \& McCulloch, G. (1996). Teacher professionalism and curriculum control. In I. Goodson \& A. Hargreaves (Eds.), Teachers' professional lives, 56-74. London and Washington DC: Falmer Press.

Hooper, S., Rieber, L. P. (1995). Teaching with technology. In A. C. Ornstein (Ed.). Teaching: Theory into practice, p. 154 170. Needham Heights, MA: Allyn and Bacon.

Hustler, D., McNamara, O., Jarvis, J., Londra, M., \& Campbell, A. (2003). Teachers' perceptions of continuing professional development. London: DfES.

Iain, D. (2011). Evaluating the Impact of Professional Development on Teaching Practice: Research Findings and Future Research Directions. US-China Education Review, 703-714.

Ifanti, A.A., Fotopoulopou, V.S. (2011). Teachers' Perceptions of Professionalism and Professional Development: A Case Study in Greece. World Journal of Education, 1(1), 40-51.

Knight, P. (2002). A Systemic Approach to Professional Development: Learning as Practice. Teaching and Teacher Education 18 (3): 229-241, Available from: https://doi:10.1016/S0742-051x(01)00066-X.

Kennedy, A. (2005). Models of Continuing Professional Development: a framework for analysis. Journal of In-service Education, Volume 31, Number 2, 235-250, Available from: DOI: https://10.1080/13674580500200277.

Lawless, K. A., Pellegrino, J. W. (2007). Professional Development in Integrating Technology Into Teaching and Learning: Knowns, Unknowns, and Ways to Pursue Better Questions and Answers. Review of Educational Research, 77(4), 575-614. Available from: https://doi.org/10.3102/0034654307309921.

Maxwell, J. A. (1996). Qualitative research design an interactive approach. Thousand Oaks, CA: Sage.

Meehan, K., Obler, S., Schiorring, E.B., \& Serban, A.M. (2002). Project overview overall summary and recommendations: One technology training project study (RP Group of California Community Colleges). Santa Ana.

Mouza, C. (2009). Does research-based professional development make a difference? A longitudinal investigation of teacher learning in technology integration. Teachers College Record, 3(5), p. 1195-1241.

Ostashewski, N. (2010). Online technology teacher professional development courselets: Design and development. Paper presented at the Society for Information Technology \& Teacher Education International Conference (SITE). Publisher: Association for the Advancement of Computing in Education (AACE), C.A.: San Diego, 2329-2334. 
Otero, V., Peressini, D., Meymaris, KA, Ford, P., Garvin, T., Harlow, D., Mears, C. (2005). Integrating Technology into Teacher Education: A Critical Framework for Implementing Reform. Journal of Teacher Education, 56(1), 8-23. Available from: https://doi.org/10.1177/0022487104272055.

Robinson, K., Aronica, L. (2015). Creative Schools. Revolution at the base of education, Bucharest: Publishing House.

Sabah, S.A., Fayez, M., Alshamrani, S.M., \& Mansour, N. (2013). Continuing Professional Development (PLD) Provision for Science and Mathematics Teachers in Saudi Arabia: Perceptions and Experiences of PLD Providers. Journal of Baltic Science Education, 13(3), 91-104.

Samarawickrema, G., Stacey, E., Warren, C. (2008). Academic staff take the lead: Experimenting with social software at Deakin University. Paper presented at the Hello! Where are you in the landscape of educational technology? Proceedings ascilite Melbourne, November 30 - December 3 2008, Melbourne, Australia, 875-884.
Stolovitch, H.D., Keeps, E.J., Rosenberg, M.J. (2017). Formarea prin transformare. Dincolo de prelegeri. București: Editura Trei.

Webb, R. Vulliamy, G., Hämäläinen, S., Sarja, A., Kimonen, E., \& Nevalainen, R. (2004). A comparative analysis of primary teacher professionalism in England and Finland. Comparative Education, 40(1), 83-107, https://doi.org/10.1080/0305006042000184890.

Truesdell, E., Birch, R. (2013). Integrating Instructional Technology into a Teacher Education Program: A ThreeTiered Approach, AILACTE Journal, 10 n1, 55-77.

Vavasseur, C.B., MacGregor, S.K. (2008). Extending contentfocused professional development through online communities of practice. Journal of Research on Technology in Education, 40(4), 517-536.

Zembylas, M. (2003). Emotions and teacher identity: A poststructural perspective. Teachers and Teaching: Theory and Practice, 9 (3), 214-238. Available online: https://doi:10.1080/13540600309378. 